\title{
Inventing the Sacred Place: the Case in Western Siberia
}

\author{
Elena V. Golovneva* \\ Ural Federal University named after the B.N. Yeltsin \\ 19 Mira Str., Ekaterinburg 620002, Russia
}

Received 24.01.2013, received in revised form 18.01.2014, accepted 06.11.2014

\begin{abstract}
This article reflects on the experience of theorizing sacred place through case-study of Okunevo village in Western Siberia. On particular, it focuses on the analysis of non-traditional religious movements in context of this Siberian village. The article opens with brief review of the meaning and content of concept "sacred place." It then reflects understudied in scientific researches interpretation of sacred place by representatives of neo-orientalism and neopaganism in Siberian region. It concludes with some comments regarding suggestions about possible social functions of sacred places in contemporary reality. Sacred place is considered as a symbolic identity-performance of different religious movements and an idea of "religious revival". The inventing of sacred space in contemporary context is connected with dissemination of local myths regarding "Chosen people", "particular energy and spiritual character of the place" and "holy Temple."
\end{abstract}

Keywords: sacred place, sacralization, non-traditional religiosity, religious myth, Western Siberia.

Research area: history, culture studies.

\section{Introduction}

This research project addresses the phenomenon of inventing and disseminating of sacred places in contemporary Russia. Various cultural practices emerge on this ground: non-traditional religions, "historical reconstructionist" movements and para-scientific aspirations. In scientific discourse sacred places can be social constructs or to be a portion of territory "intrinsically sacred", occupying an area of landscape, which has forever been regarded as holy.

What do we mean by the sacred place? And how can anthropologist research contribute to its understanding and conceptualization?

\section{Theoretical framework}

For the past fifty years sacred space has received the attention of scholars from a variety of disciplines. Scholars theorized sacred space in different and often contrasting ways, identified different lines of definition (see Kong, 2006, 2010; Wilford, 2010; Chidester \& Linenthal, 1995; Sheldrake, 2007).

Many conventional interpretations of the sacred implicitly reflect the approach of the historian of religion, Mircea Eliade. According to him, "the sacred" is "wholly other" than the mundane and separated from everyday action and experience. For religious subject, Eliade argues, "space is not homogeneous; he experiences

(c) Siberian Federal University. All rights reserved

* Corresponding author E-mail address: golovneva.elena@gmail.com 
interruptions, breaks in it; some parts of space are qualitatively different from others." (Eliade, p.20).

Postmodern approach have moved away from the Eliadian "substantional" understanding of sacred space as an "ontological given" towards its "situational" conceptualization as a social construction; as a crossroad of different narratives, meanings and social practices. Veronica della Dora supports the so called "more-than-representational" approach where two aspects of sacred - numinous and emotional are stressed: "Spatially speaking, unlike in Eliade's structuralist narrative, these aspects are not "ontological given", and thus are not necessarily confined to a self-bounded sacred space starkly opposed to profane space, but they can be articulated and sustained within "ordinary secular" (Veronica della Dora, 2011, p. 168).

As a rule, the phenomenon "sacred place" is associated with locality that produces the complex of religious ideas, myths, values and practices. Sacred place reinforces a sense that human life is sacred rather than merely an organic phenomenon. What foundation for inventing and existing of the sacred place?

In my point of view, local myths have played a particularly important role in shaping sacred places. In the long term their tension and interplay serves to mobilize religious actions and regenerate the religious communities (Smith, 1999). Local myths may push activity in different directions; but they also limit the options and present a circle of assumptions and dynamic impulses, which help to raise the self-consciousness of religious members.

The artificial character of the mythologems introduced through the efforts of religious (often charismatic) leaders can be accepted in the sphere of the religious group, but this group doesn't resist the introduction of these mythologems, it needs them.
This article deals with mythologems, disseminated in sacred places, the mythologems, which can be called the modern modifications of the archaic universal mythologems. Of course, such mythologems often change their symbolic forms and content over time in relation to different perceptions of significant others outside the community and varying degrees of conflict or competition with those outsiders.

Mythical constructs are numerous, but the ones - principal for the organizing of sacred place - are the mythologems of "Chosen people", "particular energy and spiritual character of the place", "ancient holy Temple" and "golden age", the aim of which is to bring sense to the individual existence of the religious group, and arouse the feelings of unity and greatness of one's own religion. They designate a space and time for action, a religious activity; they contain impulses for collective action and rituals.

\section{Statement of the problem}

My concern is to relate the thinking about sacred place with case in Western Siberia. Since 1980s Western Siberia has been witnessing of dissemination of non-traditional religions and syncretic spiritual doctrines. Many of them are based on significant interest to religious ideas and mythology of Indo-Iranian cultural complex. How do the people of these revival movements want to arrange their sacred place, what do they aspire to, what do they want to express, and by what means?

Sacred space could be interpreted as a symbolic identity-performance and a space for religious revival. This research is relied on social anthropology and religious studies. The results of this case-study are alleged to contribute to the discourse about the sacred place, while embedding the topic into the broader context of non-traditional religious practices and religious identity discourses. 


\section{The Siberian village as a crossroad of religions}

The subject of this research is Okunevo village in Omsk region (Western Siberia) that will be analyzing as a sample of sacred place. Being an ordinary village in Siberian region, it founds out unusual for Siberian way of life features. For example, the street with houses' fences painted with bright colourful Sunscrit inscriptions and pictures of pink elephants is considered to be the so-called Hinduistic street. Here Hinduism followers from all over the world live together with village's old locals. There are log huts colourfully trimmed with wooden patterns of Neopagans which adjoin with those of Christians and Moslems.

The conversion to Hinduism in Okunevo began in 1992 when Rasma Rositas came here from an Indian province of Khairakhan under influence of her spiritual teacher Muniradzha. He prompted her to find a place where a highlevel civilization existed 300 thousand years ago. She appeared in Okunevo and after many days' meditation session she received necessary supernatural justifications. She founded a Hinduist temple and settled in Okunevo.

At the same time scientists were carrying out research (geological, archeological, etc.) because of the place attracted general attention: local residents informed about unidentified flying objects as well as extraterrestrial supernatural phenomena. Research expeditions "confirmed" the presence of non-standard power in the territory of Okunevo. They "revealed" five lakes containing curative water and falling meteorites tracks. Many research results have subsequently been coded and they declared Okunevo as energetically abnormal place. The information about Okunevo was gradually widespread and people interested in spiritual practices came to Okunevo from all over the world.
People leave former employment for to live in Okunevo. Due to unemployment, local residents consider it right and proper to move to the city or a larger settlement. Religious pilgrims buy their houses willingly and with no expensive prices. Many of Okunevo "guests" are people successful in modern city reality having good jobs and high incomes. But in spite of this, they "choke" with spiritual impoverishment as a consequence (result) of spiritual vacuum after atheistic system destruction. They came to Okunevo to fill internal spiritual space and implement this internal human need.

There is a ceremonial place in 300 meters off the village located on a heightened terrace of the Tara river high bank. Archeological research data of the area testify arrangement of a number of burial grounds coming back to the epoch from the Stone Age up to XVII-XVIII centuries. Therefore, for thousands of years the cape and the territory around it had specific sacral meaning and cult objects were arranged there. A Christian chapel, a Hinduist altar, a Pagan swastika (fylfot) and a grove coexist here on a space of just tens meters. Different confessions representatives carry out their rituals here.

They respect other religions, visit different religious ceremonies, have friendly relationships and practice mutual aid. People of different religions have love affairs (he is a Hinduist and she is a Moslem, for example). In their religious search, some of them converse from one confession to another one, others "unite in them" some religions.

They often use rituals aimed at help of supernatural forces. Belief in supernatural ideas is a dominating factor and in this sense various religious specific features get on and coexist peacefully. All these people are unified in their confidence that Okunevo is a place of Russia's and the mankind spiritual revival and it will be the centre of a new developed 
civilization like that of existing 300 thousand years ago.

Nowadays, Orthodoxy is officially preferable in Western Siberia because its history is inseparably connected with Russian statehood and culture formation. But humanistic traditions must not be expressed in standard mandatory ideologic(al) form. In post-Soviet epoch the possibility of free world look and religious pluralism appeared. In this connection the role of non-traditional religiousness in Western Siberia has become notable (including neo-orientalistic cults, i.e. oriental religions (Buddism, Hinduism). Their main purpose is confirmations of ideas, humanistic values that formulated and interpreted in different ways.

An attractive point for adherents is return to external objective reality form by renunciation of extraneous attachments. Any person can do sacred rituals independently from social status, education and occupation. These doctrines aspire to change personal life, not social environment. It occurs that update non-traditional religious forms serve as a real worldview alternative to traditional religions. It provides a cultural frame for an alternative discourse. Based upon these foundations, a religious counterculture is being formulated; its adherents are constructing an 'Other World' and building an 'anti-discourse', in opposition to the official ones.

\section{Sacred place in view of Babadzhi doctrine}

Okunevo is becoming a distinctive spiritual center of Western Siberia where exsotic and unknown religion doctrines exist. The Babadzhi doctrine and Neopagan one play a key role among them.

The Babadzhi doctrine is the most interesting of Western Siberian neo-orientalism doctrines. It was founded by Shri Haidakhan Vale Baba (or Babadzhi), who was an Indian guru.
$\mathrm{He}$ is considering by its supporters as Shiva's incarnation the 1970-1980s.

According to Babadzhi, our epoch, which characterizes of social degradation, comes to end. Some space catastrophe is coming. To avoid it, people must live in harmony with the Universe, must concentrate their mind on Om Namaha Shivaija mantra. They should respect the Fire as incarnation of God creative energy.

In Babadzhi point of view, Russia is a basic spiritual center on the Earth, where religious revival will begin. The concept of Siberia is the most important for Babadzhi. He declared that a central sanctuary of global scope - Hanumana's temple - existed in Siberia in ancient times. From that place Arii brought Vedas to their new motherland. Here, in Siberia, the events, which were described in ancient Indian poem "Ramayana", were happening. Babadzhi connected Russia's salvation in coming catastrophe with temple's revival.

The doctrine supporters considered the environs of Okunevo village (Omsk region) as such a place. They founded ashram Omkar Shiva Dhams and sanctuaries where Vedic ceremonies are held every day. The toponimic data played a key role in choice of sacred center. Particularly, the name of Omsk city was connected with one Indian word Om (God created the Universe, saying this word). The name of Tara town / Tara river is compatible with name of Indian Godness.

The first vedic ritual (Havan) was held by Rasma Rositas in Okunevo the 6 June of 1992. It is symbolized a revival of sacred sanctuarity. Later a memory sign was founded in this place. It was column with table where a sign Om was painted in red circle and black frame. Rasma founded ashram for making fire ritual (duni) near her own house. 300 meters off the village a ceremonial place where Hinduist altar exists now was founded. Many babadzhist's adepts from the 
Netherlands, England, Germany, etc. have been here.

One of the axioms in the basis of neoorientalist cults is the idea that different Holy Writs in the final analysis teach some single Siddhanta. It means that an ultimate aim of all spiritual searches is unique. Spiritual practice of different forms (Vedic sacrifice, duties's disinterested discharge, worship to davas and Gods who are in charge of the Universe's activity different aspects, yoga, meditation on impersonal Absolut, Spirit and Matter philosophical interpretation) is considered to be one of constant spiritual development stages. The climax of this way is love to God and sacrificial absolutely disinterested service to him. Bhagavadgita informs that all the ways pointed in Vedas lead to personal God cognition. Religion in its ceremonial sense is private case (different manifestations) of love to God. Its development is the highest point of human personal spiritual search. In other words it is God and interconfessional love to God is the basis of different religions cooperation.

Such attitude to religion and the presence of similar doctrines in modern Russia cause diverse reactions. There is often an opinion that fashion for oriental cults, adore for non-traditional religiousness is transient and perfunctory. The situation is more difficult and complicated with Western Siberia: active cooperation with the Arian world (including that of mythology aspect) during the Bronze Age and the early Iron Age were an important factor, defining the direction of Siberian ethnic cultural development. Therefore, neo-orientalism phenomenon may be considered as a particular form of extremely ancient worldview complex revival (Yashin, 1997).

Representatives of neorientalism in Omsk region (Omkar Shiva Dham, Tara Dharma Center, Veda's Center of Makarishi) inform about Northern ancestral home of Vedic expansion in Siberia. According to Shri Makarishi supporters, that guru insisted on the fact of the first transcendental meditation center of Asian Russia establishing in Western Siberia. Moreover, that region is notable for peculiar spirituality and sacral purity energy (Yashin, 1997).

Nowadays the idea about Zaratustra motherland in southern Ural region (Arkaim) is popular in mass consciousness. The similar way, Zoroastrism and ancient Arian cults are considered as ancient Ural nation primordial religion (Shnirel'man, 1999).

\section{Sacred place: Neopagan interpretation}

Okunevo in Western Siberia is considered to be a sacred center of religious revival by Neopagans too. Neopagan order members "Dzhiva" in Omsk believe that Arian predecessors lived in Daaria country in Arktida which was located on the territory of contemporary Siberia, and sacred town-temple Asgard was on the place of modern Omsk. Asgard was a city of gods in Scandinavian mythology and great Temple of the Earth was situated here. Due to some space catastrophe, protoarii left the place which caused their culture decline and beliefs degradation.

In point of view of Neopagans, the most detailed, original doctrine was preserved by Slavs and the Iranians. Vedic Ariies mixed with the Indians that caused the doctrine's mispresentation (so, in particular, Indoariis asuru are considered not as blami but as evil spirits).

Neopagan (Engliism) organization was founded in 1992 by Alexander Hinevich. The community's activity is financed by parishioners sponsors contributions and its own commercial organizations "Asgard" and "Iriy" involved in building and consulting. Teenagers and young people, especially under- and postgraduate students, are predominant among Omsk engliists. They are attracted with exotic rituals and special spirit atmosphere. The community exists as a 
secret order and there is no any information about its activity for another people.

One of engliism's aims is consolidation of all modern Neopagans. As a result Hinevich is getting in touch with different neopagan communities of Russia, Europe and the USA. But Hinevich believes that slavs pagans save engliism faith in pure form and the Russians are the most ancient ethnic group on the Earth, keeper of the sacred knowledge.

According to Hinevich, engliists respect sacred books of all religions, but the most important are considered ancient Russian vedic scriptures (Velesova Book, Perun book, Russian Vedas etc). These books were written on sacral daar language, which Hinevich knows alone. The engliist church doctrine includes the preposition about world's multiplicity (material and spiritual), about their hierarchy. Russian patriotism, devotion to tribal ideals and respect to all living creatures on the Earth are considered to be ethic principals.

Engliists respect ancient slavs gods (SvarogPerun-Sventovit, Lada Godness and sacred ancestors) which are considered as incarnations of one God. According to them, a person was involved in space fight of evil and kind forces. The world of spirits consists of light and dark worlds. At the same time, engliism criticizes Christian church for distortion of truly faith (Yashin, 2001).

Although the ideology of the movement can undergo certain changes, its main idea focuses on the creation of the new society free of violence and aggression, living in harmony with physical environment and the nature. The practical steps to achieve the goal are, as declared by the leader, (1) moral and spiritual perfection of the movement followers; (2) establishment of new social relations within the community; (3) attempts to give up modern technology, values of mass culture and all activities leading to 'pollution' of natural environment and human body.

Participants of this community are fostering ethnic revival: not only remembering the glorious past, but also rebuilding it, here and now. Paganistic national visions are based on a unique interpretation of ethnic proto-history, a strong commitment to non-Christian, "ancient" roots of ethnic culture and a spiritual concept of the nation. The movement's legitimacy is based on a presumed continuity with the cultural heritage of pagan ancestors. As detailed historical continuity is broken for almost a millennium, native faith movements have to invent their own traditions.

\section{Social functions of sacred place}

The importance of such ideas in Okunevo resident's consciousness allows to raise a question of their religious practice conversion basis. In my point of view, a reason for such conversion is the presence of eschatological motives connected with different circumstances at their consciousness.

It is as well an ideological doctrine accompanied with state ilimination from the sphere of an individual stratification and generates the realization of one's own unclaimedness. First, it is different aspects of environmental problem (from habitat's destruction to natural resources exhaustion). Secondly, it concerns economic instability and widespread private sensation instability when life is like a race with fear to be a loser. Finally, it is fear of globalization wave.

It leads to the importance of private experience and subjectivity disclosing sphere reduction. The search of illusory overcoming difficulties means (conversion to religious practices in particular) is natural in such a situation. The demand for religious conceptions (both new and traditional) is explained with that they create a prospect of personal clear and 
accessible activity providing many problems solution. Iindividual coping mechanisms are associated with "groupist" answers; participants are urged to connect their personal problems and values to religious group narratives. Late-modern alternative spiritualities, processes of individual identity-building and nationalist "groupist" thinking are interconnected.

\section{Conclusion}

As we seen, the inventing of sacred space in contemporary context is connected with dissemination of local myths regarding "Chosen people", "particular energy and spiritual character of the place" and "holy Temple." The myths are turned to be the crucial in constructing sacredness even in epoch of scientific knowledge and modern technologies. What the reason for this?

Nowadays people's heightened interest to sacred places, religious centers like that of Okunevo is a reaction to unification and massovization and can be interpreted as individual's self-realization compensatory form. Peculiar circumstances, special knowledge and secret are logic, natural and accessible ways of breaking out routine, daily occurrence and possibility for expressing themselves. In places like that of Okunevo, it is important to have underlined substandardness, informality or peculiarity of religious organizations in comparison with religious dogmatism considered as a corresponding channel of individual processing. A modern individual lives in the world where comfortable moderated democratic unfreedom reigns. As a result, one of the most attractive parts of such places visiting is freedom sensation, which seems necessary to provide individual's realization opportunities.

Okunevo plays an important role as a distinctive spiritual center of Western Siberia where religious identity preservation doesn't exclude a prevalent aim at communication, equality and cooperation with other religious communities representatives. Nowadays the role of Okunevo in Western Siberian spiritual life is rather notable due to coexistence of different religious traditions, cooperation local interests with interests of international religious unions. Scientists should pay attention to this place and do some complex researchers here.

\section{References}

1. Chidester, D. \& Linenthal, E. T. (1995) American Sacred Space (Bloomington: Indiana University Press).

2. Eliade, M. (1959) The Sacred and the Profane: The Nature of Religion (New York: Harcourt, Brace \& World).

3. Kong, L. (2006) Religion and spaces of technology: Constructing and contesting nation, transnation, and place, Environment and Planning A, 38, pp. 903-918.

4. Kong, L. (2010) Global shifts, theoretical shifts: Changing geographies of religion. Progress in Human Geography, OnlineFirst, published on 30 March 2010. doi:10.1177/0309132510362602.

5. Sheldrake P. (2007) Placing the Sacred: Transcendence and the City. Literature \& Theology, Vol.21, No.3, pp. 243-258.

6. Shnirel'man V (1999) Passions about Arkaim: Russian. Nationalism, the Aryans, and the Politics of Archaeology. Inner Asia 1, pp. 267-282.

7. Smith, A. (1999) Myths and Memories of the Nation (Oxford University Press).

8. Veronica della Dora (2011): Engaging Sacred Space: Experiments in the Field. Journal of Geography in Higher Education, 35:2, pp.163-184. 
9. Wilford, J. (2010) Sacred archipelagos: Geographies of secularization. Progress in Human Geography, 34(3), pp. 328-349.

10. Yashin V.B. Drevnerusskaia ingliisticheskaia tserkov` pravoslavnykh staroverov-inglingov [Old Russian engliist church of orthodox old-believers-engliings]. Neoyazychestvo na prostorakh Yevrazii [Neo-Paganism on the Expanses of Eurasia]. Moscow: Bibleisko-bogoslovskii institut sv. Apostola Andreia [Biblical-Theological Institute of the Holy Apostle Andrew], Moscow, 2001. pp. 56-67. (In Russian)

11. Yashin V.B (1997) Ariano-sibirskie kontakty $v$ drevnosti $i$ sovremennye marginal'nye dukhovnye ucheniia [Arian and Siberian contacts in ancient times and modern spiritual marginal teachings]. "Rossiya i Vostok: philologiya I philosophiya". Materialy Vserossiiskoi nauchnopracticheskoi konferentsii (Proc. Scientific and Practical Conference "Russia and East: philology and philosophy). Omsk: Omsk State University, 1997, pp. 62-66. (In Russian)

\section{Конструирование сакрального места: случай в Западной Сибири}

\section{Е.В. Головнева}

Уральский федеральный университет им. Б.Н. Ельцина Россия, 620002, Екатеринбург, ул.Мира, 19

В данной статье изложено теоретическое обоснование понятия «сакральное место» на примере деревни Окунево в Западной Сибири. Особое внимание уделено, в частности, анализу нетрадиционных религиозных движений в данной сибирской деревне. Статья начинается с краткого рассмотрения значения и содержания конџепта «сакральное место». Далее представлена недостаточно изученная в науке интерпретация сакрального места последователями неориентализма и неоязычества в сибирском регионе. В конце статьи дано авторское представление о возможных сочиальных функциях, характерных для сакральных пространств в современной реальности. Сакральное место рассматривается как символическое пространство для воспроизводства идентичностей в рамках религиозных движений и как идея «религиозного возрождения». Конструирование сакрального пространства в современном контексте оказывается связанным с распространением локальных мифов об «избранных людях», «особой энергетике и духе места», о «священном Храме».

Ключевые слова: сакральное место, сакрализация, нетрадиционные религиозные движения.

Научная спеииальность: 07.00.00 - исторические науки, 24.00.00-культурология. 